\title{
Svårt för lärare att bedöma laborativt arbete rättvist
}

\author{
Emilia Fägerstam \\ Linköpings universitet
}

Laborationer anses vara en viktig del i skolans undervisning i naturvetenskap och elevernas förmåga att arbeta praktiskt ska bedömas i de nationella proven. En ny studie visar att det är svårt för lärare att göra en individuell bedömning av elevernas praktiska arbete.

\section{Laborativt arbete}

Syftet med laborationer är att elever ska utveckla sin förståelse för naturvetenskap och den vetenskapliga processen, men också att de ska lära sig grunderna för praktiskt arbete i laboratorium. I de nationella proven i år nio bedöms de individuellt på sin förmåga att utföra praktiskt laboratoriearbete. En studie från Mälardalens högskola visar att många händelser i klassrummet kan hindra lärare från att göra en rättvis individuell bedömning av elevernas praktiska arbete [1].

Hindren som forskaren såg handlade främst om tre olika aspekter av provsituationen. Dessa var elevers interaktion med varandra, lärares interaktion med elever, samt praktiska problem som uppstod när lärarna skulle genomföra bedömningarna.

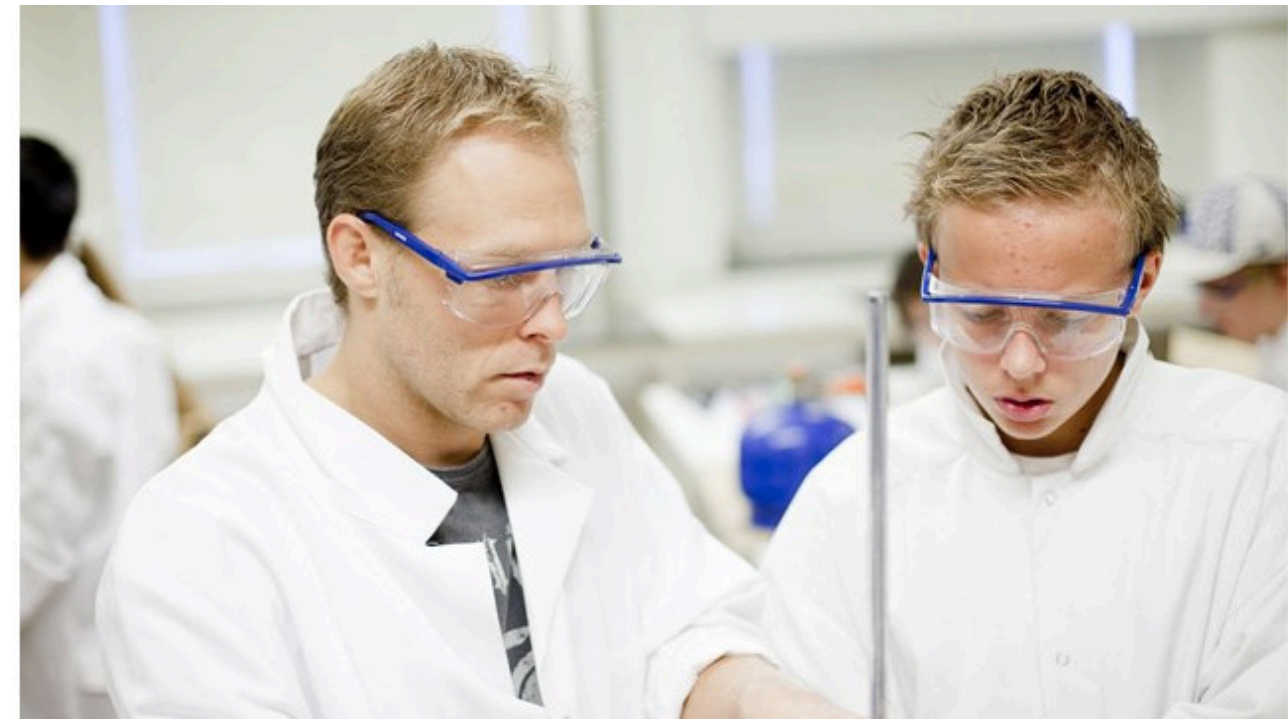

Figur 1. Rättvis bedömning av laborativt arbete påverkas bland annat av interaktioner i laborationssalen.

\section{Svårt undvika kommunikation}

När det gällde elevernas interaktion så handlade det om att de påverkade varandra så att bedömningen inte blev helt individuell. Till exempel var det svårt att undvika att eleverna härmade varandra när de valde vilket materiel eller vilka arbetssätt de skulle använde. Det var också svårt 
att hindra eleverna från att småprata eller kommunicera genom blickar och ansiktsuttryck.

Att lärarna ibland samtalade med eleverna motverkade också en rättvis bedömning. Trots att lärare och elever egentligen inte ska samtala under provet hände det att lärarna hjälpte eleverna. Det kunde då röra sig om uppmuntrande leenden som bekräftelse på att eleverna gjorde rätt, eller att eleverna fick lov att börja om när de förstod att de var på fel spår. Detta kunde även andra elever se och höra, vilket gjorde att också de fick viss ledning.

\section{Praktiska hinder för rättvis bedömning}

Det fanns många praktiska förhållanden som kunde ställa till det vid bedömningen. En sådan var att provsituationen gjorde det svårt för lärarna att ha överblick över salen, vilket i vissa fall gjorde att de inte såg när elever gjorde något som kunde vara ett kriterium för ett högre betyg.

Ett annat problem uppstod till följd av att eleverna var indelade i tre grupper som gjorde laborationen i tur och ordning. Till exempel så kunde elever se tidigare elevers märkningar på bägare och dra nytta av det. Genom att se vilket material som var diskat kunde de också förstå vad de själva skulle använda i sitt experiment. Detta innebar alltså ett hinder för en rättvis bedömning. Det kunde också vara tvärtom, att det blev svårare för elever som kom efter en annan grupp. Elever hällde till exempel ofta tillbaka överblivna kemikalier i ursprungsbägarna, och hällde då ibland tillbaka i fel bägare. Detta kunde göra resultaten felaktiga eller svårtolkade för de elever som sen använde dessa kemikalier.

Resultaten visar alltså att det är svårt för lärare att göra rättvisa individuella bedömningar. Enligt forskaren är det snarare elevgruppens gemensamma arbete som läraren bedömer. Författaren tror att svårigheterna som lärarna i den här studien stod inför är något som förmodligen kan kännas igen på andra skolor, även om det bara var två lärare och 38 elever som deltog i studien.

Resultaten i studien baseras på analys av video. För att kunna se vad eleverna och lärarna gjorde videofilmades klassrummet från två håll. Dessutom fick tre elever i varje grupp bära en typ av glasögon som spelar in det som eleven skriver ner, tittar på, hör eller säger. De olika filmerna jämfördes sedan.

\section{Hur kan bedömningen bli mer rättvis?}

Författaren ger förslag på hur bedömning av praktiskt arbete kan utvecklas. Till exempel skulle bedömningen av elevers praktiska arbete kunna delas upp så att en del består av uppgifter som eleverna utför på de vanliga kemilektionerna. Detta skulle sen kunna kombineras med ett mindre individuellt test liknande det som ingår i det nationella provet. På så sätt bedöms eleverna mer rättvist genom att det blir mindre konstlade förhållanden, och att de får fler tillfällen att visa sin individuella förmåga.

Ett annat förslag är att eleverna får arbeta i mindre grupper, även om de bedöms individuellt. Då behöver inte elevers samspel med varandra ses som ett hinder utan snarare som en tillgång. Förmåga till samarbete och kommunikation är förmågor som värderas i arbetslivet. Elevernas samtal och diskussioner under praktiskt arbete i kemi kan bli ett tillfälle för lärande och samtidigt ge läraren inblick i vad eleverna behöver för stöd i sitt fortsatta lärande.

\section{Bakgrund: Nationella praktiska provet i naturvetenskap}

I de nationella proven i naturvetenskap i år nio ingår bedömning av individuellt praktiskt laboratoriearbete. För att eleverna ska få en rättvis bedömning ska alla elever i Sverige göra samma laboration och lärarna får detaljerade instruktioner om vad de ska bedöma. I instruktionerna står att lärarna ska observera eleverna individuellt och bedöma dem efter en 
tregradig skala, E, C och A. Eleverna ska arbeta självständigt och får inte samtala med vare sig varandra eller med läraren under provet.

\section{Lärarpanel}

Anders Hackzell är lektor på Fullriggaren Malevik i Kungsbacka och undervisar elever på högstadiet. I hans kollegium har man liknande erfarenheter som de som tas upp i studien, till exempel att elever söker bekräftelse från läraren att de är på rätt väg och att det är svårt med överblicken i klassrummet.

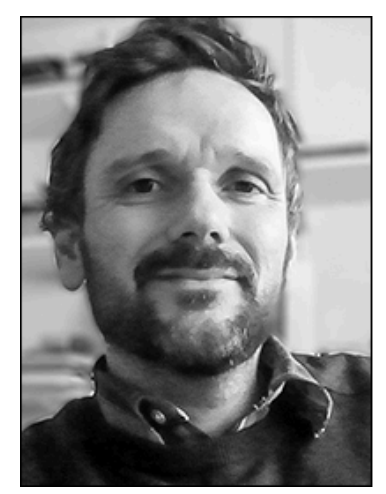

Figur 2. Anders Hackzell

- Att skapa förhållanden som gör det möjligt att bedöma alla elever individuellt och rättvist i så flyktiga skeenden är alltid mycket svårt, enligt Anders Hackzell.

Anders menar vidare att svårigheterna med bedömning vid detta prov visar betydelsen av att lärare inte lägger för stor vikt vid detta enda bedömningstillfälle när det kommer till att sätta slutbetyg för en enskild elev. Han anser att underlaget för betygsättningen istället i huvudsak bör utgöras av bedömningar från den övriga undervisningen och att delprovet istället har sitt största berättigande genom att fungera som ett bedömningsstöd för att nå en mer likvärdig bedömning lärare emellan.

En sak Anders skulle vilja veta mer om är vilken syn eleverna har på provet, om de anser att de blir sedda och bedömda på ett rättvisande sätt och om det skiljer sig från lärarnas upplevelse. Vidare tycker han att det hade varit intressant att veta om eleverna anser att de får tillräckligt med stöd från de skrivna instruktionerna för att förstå hur de ska genomföra provet.

- Detta skulle kunna ge en bakgrund till deras agerande vid provet vilket skulle kunna ge kunskaper om hur man kan förbättra möjligheterna för lärarna att se varje elevs individuella förmågor.

Han menar avslutningsvis att förslaget att i provet bedöma förmågan att samarbeta är intressant men så som kursplanerna ser ut idag är det inget som är befogat att bedöma vid ett nationellt ämnesprov då denna kompetens inte uttrycks bland kunskapskraven för ämnena.

- Detta kan man anse vara en brist då dessa förmågor som det nämns i referatet är av största vikt för eleverna i ett framtida yrkesliv. Men det är snarare en fråga för framtida revideringar av kursoch läroplaner än för konstruktionen av nationella prov, enligt Anders Hackzell.

\section{Notering}

Denna text har tidigare publicerats på Linköpings universitets hemsida. 


\section{Referenser}

1. Sund P. Science teachers' mission impossible?: A qualitative study of obstacles in assessing students' practical abilities. International journal of science education. 2016;38(14):2220-38. 